\title{
Mammalian Glycan
}

National Cancer Institute

\section{Source}

National Cancer Institute. Mammalian Glycan. NCI Thesaurus. Code C118431.

An oligosaccharide protein modification that is synthesized by mammalian cells. 